\title{
Establishing a cohort in Central Brazil: Strategies and challenges.
}

\author{
Estabelecendo uma coorte na Região Central do Brasil: Estratégias e desafios. \\ Estableciendo una cohorte en la Región Central de Brasil: Estrategias y desafíos.
}

Received: 06/08/2021 | Reviewed: 06/19/2021 | Accept: 06/21/2021 | Published: 07/04/2021

\author{
Claudio Morais Siqueira \\ ORCID: https://orcid.org/0000-0003-0527-9349 \\ Universidade Federal de Goiás, Brazil \\ E-mail: claudiomorais@ufg.br \\ Valéria Christina Rezende Feres \\ ORCID: https://orcid.org/0000-0002-9843-2949 \\ Universidade Federal de Goiás, Brazil \\ E-mail: vcrisrezende@gmail.com \\ Livia Aires Coutinho \\ ORCID: https://orcid.org/0000-0002-7605-4692 \\ Universidade Federal de Goiás, Brazil \\ E-mail: lacoutinho2015@gmail.com \\ João Bosco Siqueira Júnior \\ ORCID: https://orcid.org/0000-0002-2574-2495 \\ Universidade Federal de Goiás, Brazil \\ E-mail: joao.siqueira@ufg.br
}

\begin{abstract}
Dengue is considered the most important acute febrile arbovirus in the world due to its burden on morbidity and mortality of countries. Cohort studies are appropriate for understanding dengue transmission dynamics and establishing baselines prior to the adoption of new control strategies. However, these studies pose major operational challenges that tend to hinder their execution, especially in developing countries. The strategies used in implanting and conducting a cohort in Central Brazil (city of Goiania) are presented, including the approaches adopted to overcome the challenges observed. The following steps are described and discussed: defining the field work team, establishing partnerships and the recruitment of participants; the initial serosurvey; technology in field research; and monitoring and evaluation of febrile episodes. A partnership between academia and public health services was the adopted approach and participation of the Municipal Health Secretariat and the Family Health Teams was essential for the proper implementation and conduction of the study. In return, the researchers' performance favored the Health Service through surveillance and health care activities of the population. This interinstitutional experience was successful with benefits for both institutions.
\end{abstract}

Keywords: Dengue; Cohort studies; Universities; Public health services; Intersectoral collaboration.

\section{Resumo}

A dengue é considerada a mais importante arbovirose do mundo pelo seu impacto na morbimortalidade dos países. Estudos de coorte são adequados para compreender a dinâmica da transmissão da dengue e estabelecer linhas de base antes da adoção de novas estratégias de controle. No entanto, esses estudos apresentam grandes desafios operacionais que tendem a dificultar sua execução, especialmente em países em desenvolvimento. As estratégias utilizadas na implantação e condução de uma coorte na região na cidade de Goiânia-GO, Brasil, são apresentadas, incluindo as abordagens adotadas para superar os desafios observados. São descritos e discutidos os passos: definição da equipe de trabalho de campo, estabelecimento de parcerias e recrutamento de participantes; o inquérito sorológico inicial; tecnologias em pesquisa de campo; monitoramento e avaliação dos episódios febris. A parceria entre a academia e os serviços públicos de saúde e a participação da Secretaria Municipal de Saúde e das Equipes de Saúde da Família foram fundamentais para a execução e condução apropriadas do estudo. Em contrapartida, a atuação dos pesquisadores favoreceu o Serviço de Saúde por meio de ações de vigilância e atenção à saúde da população. Essa experiência interinstitucional foi bem-sucedida, com benefícios para ambas as instituições.

Palavras-chave: Dengue; Estudos de coortes; Universidades; Serviços públicos de saúde; Colaboração intersetorial.

\section{Resumen}

El dengue es considerado el arbovirus más importante del mundo por su impacto en la morbilidad y mortalidad en los países. Los estudios de cohortes son adecuados para comprender la dinámica de la transmisión del dengue y establecer líneas de base antes de adoptar nuevas estrategias de control. Sin embargo, estos estudios presentan importantes desafíos operativos que tienden a dificultar su ejecución, especialmente en los países en desarrollo. Se presentan las estrategias utilizadas en la implementación y conducción de una cohorte en la región en la ciudad de Goiania-GO, 
Brasil, incluyendo los enfoques adoptados para superar los desafíos observados. Se describen y discuten los pasos: definir el equipo de trabajo de campo, establecer asociaciones y reclutar participantes; la encuesta serológica inicial; tecnologías en investigación de campo; seguimiento y evaluación de episodios febriles. La alianza entre la academia y los servicios de salud pública y la participación del Departamento de Salud Municipal y los Equipos de Salud de la Familia fueron fundamentales para la correcta ejecución y conducción del estudio. Por otro lado, el trabajo de los investigadores favoreció al Servicio de Salud a través de acciones de vigilancia y atención a la salud de la población. Esta experiencia interinstitucional fue exitosa, con beneficios para ambas instituciones.

Palabras clave: Dengue; Estudios de cohortes; Universidades; Servicios públicos de salud; Colaboración intersectorial.

\section{Introduction}

Dengue is considered the most important acute febrile arbovirus in the world due to its burden on morbidity and mortality in countries (Simmons, et al., 2012). The disease occurs endemic in more than 100 countries with tropical and subtropical climate (Martina, Koraka, Osterhaus, 2009) and has become a pandemic throughout the world over the last 50 years, with an increasing incidence of the disease in countries in Africa, Asia, the Americas and Europe (Guzman \& Harris, 2015; Medronho, 2009; WHO, 2009; WHO, 2012).

The disease is endemic in Brazil since 1986, and was initially observed in large urban centers in the southeast and northeast of the country. Over the following decades, it became endemic/epidemic in 25 of the 27 states of the country, affecting municipalities of all population sizes (Brasil, 2014). From the 2000s onwards, increased frequency of disease, more severe cases and more hospitalizations were observed. The largest epidemics were recorded in 2002, 2008, 2010, 2013, 2015, 2016 and 2019, generally reflecting the introduction of new serotypes or the change in the predominant serotype of the circulating virus (Goiania, 2019; Siqueira et al., 2004).

Current dengue control strategies have been very limited in preventing outbreaks (Araújo et al., 2015; Baldacchino et al., 2015), leading to the development of new technologies, including vaccine development and new vector control approaches. Given the complexity of factors involved in dengue transmission, it is essential to understand the transmission dynamics and the determinants of the disease for future impact assessments of these new technologies (Luz et al., 2003; Yoksan et al., 2009).

From this perspective, cohort studies are the most adequate design to understand dengue transmission dynamics and establish baseline indicators prior to the adoption of new control strategies. However, these studies present major operational challenges that tend to hinder its execution, especially in developing countries (Kuan et al., 2009). In this article, we present the strategies used to implement and conduct a cohort study in the city of Goiania, capital of the state of Goias, in Central Brazil.

\section{Methodology}

\section{Study design and site}

This is an experience report, in which we described and discussed the implementation and conduction of a prospective cohort with the goal of recruiting and monitoring a sample of 2,017 children and adolescents aged over two years. An Experience Report is a descriptive study that aims to describe a successful experience that can contribute to the construction of knowledge in the area in which it was developed. It is a narrative in which knowledge is transmitted with scientific input (Grollmus \& Tarrés, 2015).

This cohort was intended to be followed clinically and laboratory for 48 months. Participants were living in 17 neighborhoods of the Northern District of Goiania-GO, Central Brazil (Figure 1). 
Figure 1: Health Sanitary Districts and location of the Northern Sanitary District of Goiania-GO, Brazil, 2015.

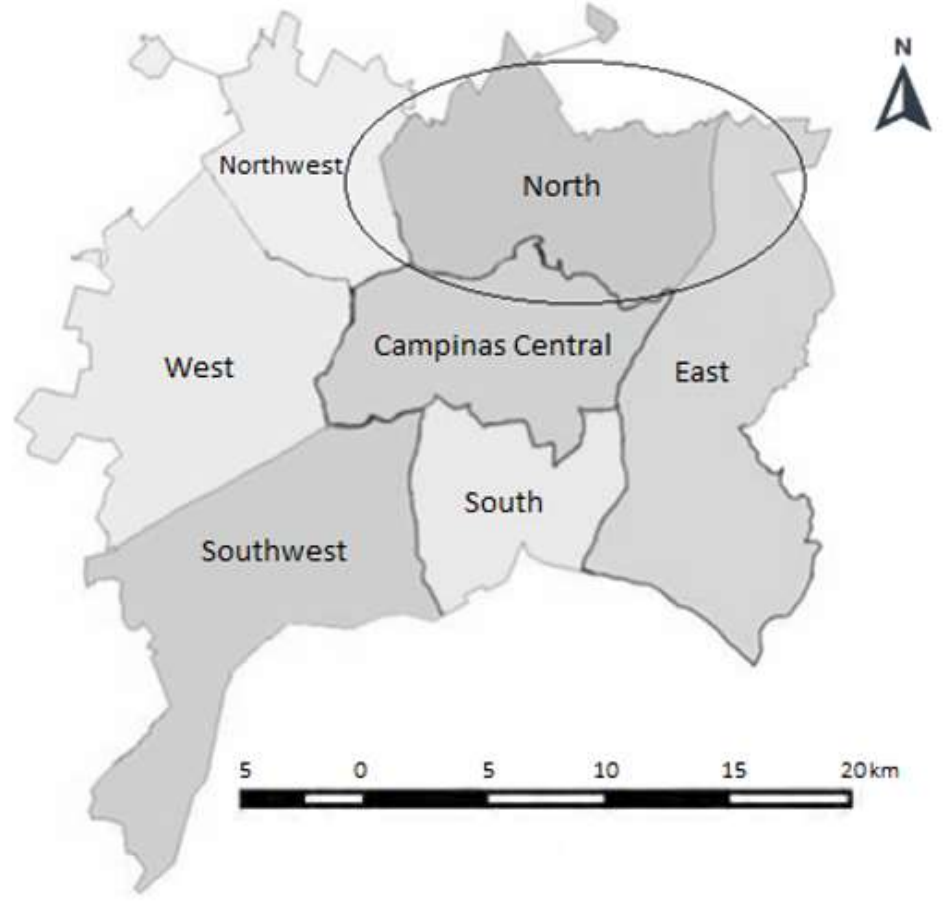

Source: Municipal Health Department of Goiania (2016).

Neighborhoods in this District are mainly made up of houses and a few low-rise buildings, where families of low or medium socioeconomic pattern reside.

The study was conducted between May 2015 and April 2019. The estimated population of Goiania for 2015 was $1,430,697$ inhabitants (IBGE, 2015) and the city is located in a semi-humid tropical area with dry winter and rainy summer.

\section{Ethics statement}

This research was approved by the Research Ethics Committee of the Medical School of the University of São Paulo (IRB no. 507/13). Informed written consent was obtained from the parents or legal guardian of the patient before inclusion in the study.

\section{Results}

\section{Defining the study team, partnership building and participant recruitment}

The initial activities for the development of the study were divided into two lines of action, after the ethics committee approval. The first was the creation of a multiprofessional team involving a general coordinator (epidemiologist), a field coordinator (pediatrician), laboratory professionals, field workers (nurses, biomedical and nursing technicians) and the supporting staff for phone calls and data entry.

The second initial action referred to meetings with the senior staff of the Municipal Health Secretariat (MHS) of Goiania to present the study design and objectives and establish a cooperation with the institution. The study area was then indicated by the MHS, based on two criteria: 1) the presence of structured and active Family Health Strategy Teams (FHST) for the broadcasting of the research and fieldwork; and 2) an area where participants were less likely to migrate. The Family Health Strategy in Brazil has been previously described. Briefly, each family health team is minimally composed by a doctor, a nurse, a nursing technician or assistant, and the Community Health Agents (CHA). CHA live in the territory covered by a 
FHST and are well aware of the characteristics of the community, each being responsible for monthly supervision of a part of this territory that contains a maximum of 750 people (Brasil, 2017). Therefore, the selection of an area with FHST was due to this close interaction between the CHA and the families, facilitating the researchers' access to families with potential study participants.

Following the selection of the study area, meetings were held with the FHST members (physicians, nurses and CHAs). These discussions were conducted with the presence of a central or district MHS manager. During this first step, the epidemiological scenario of dengue in Brazil and Goiania and the research objectives were presented. Concomitantly, meetings were held with additional partner institutions located in the area, such as schools, social centers, religious institutions, to promote the project to their employees and members.

At the next step, the CHA indicated the names and addresses of the families who had members in the target age groups in their areas of coverage and began to disclose to the community the project proposals. Then, home visits were made to invite them to participate in the research. Priority was given to families who had their own residence in the study area and those who rented, but who had been living in the same place for over a year.

The fieldwork started with a pilot study with the first 50 participants among the families suggested by the CHA with a refusal participation rate of $18.8 \%$. The pilot evaluation was carried out with the entire team in order to identify difficulties and improve all fronts and flows of activities.

The strategies adopted to reduce the refusal rates and improve the overall conduction of the study included: 1) the presence of the pediatrician to invite the families to participate at the time of the initial visit; 2) the convenience to carry out visits during holidays and weekend for the initial serosurvey; 3 ) home visits by the pediatrician, even on weekends or holidays, to evaluate fever episodes among participants already recruited. This strategy helped to disseminate the medical care provided by the study among families of the neighborhoods, representing a strengthening of the interpersonal communication of the project proposal; and 4) the inclusion of the pediatrician into the MHS professional registration system in order for treated patients to retrieve the prescription drugs free of charge when available from the public health system.

\section{Initial Serosurvey}

At the first visit, a blood sample was collected to determine the participant's serological status at the baseline of the study.

The main challenge observed at this step of the field work routine was a higher refusal rate of those responsible for children between two and four years of age to participate in the project, mainly due to concern regarding the blood collection. Phlebotomy may pose as a challenge even to more experienced health professionals. To address this concern, those responsible were instructed not to try more than one collection on the same day, rescheduling a new appointment for a second attempt. This issue was taken into account before the study started and one of the members of the fieldwork team was a nurse with the expertise for blood collection among younger children. This nurse was in charge of the second attempt if necessary. Despite this strategy, some families gave up participating in the project after the first collection attempt failed. However, over time, $35 \%$ of these families requested a new visit from the study group and allowed further attempts, as they received information from other participating families about the benefits of medical evaluation in cases of fever. A second problem was the difficulty in allowing blood collection from participants who required re-collection 14 days after the onset of fever. As they, in this phase of the disease, were already asymptomatic, some guardians presented resistance in the collection, even after explaining the importance of the exam in an attempt to confirm the diagnosis of dengue.

Another difficulty observed at the early stages of the field work, was that the recruitment of participants and the completion of the first survey was taking more time than previous estimated. The adopted strategy to improve this issue was 
the hiring of nursing technicians and nurses from the FHST at the research territory. Thus, the recruitment of participants started to be performed both at households or health facilities visits. The inclusion of these professionals was fundamental, facilitating the participation of many families due to the close relationship between the FHST and families in the study area.

\section{The technology in field research}

The advantages of using electronic devices such as GPS, tablets, among others in the operationalization of field research have been described (Kuan et al., 2009). However, due to the increasing public safety issues in Brazil, priority was given to manual filing due to the risk of burglary in the study region. Still, a doctor's computer, two cell phones, and a car were stolen during field activities and armed robbery occurred. It was decided not to use the single-member field team, preferably with one male member in each pair, as an attempt to alleviate urban violence.

\section{Monitoring and evaluation of febrile cases}

The monitoring of febrile conditions was performed by weekly telephone calls, and the presence of a history of fever, skin rash or an infectious condition suggestive of dengue was questioned. Additionally, at the time of recruitment, the guardians of the children / adolescents were instructed to contact the pediatrician directly via telephone calls, Short Message Service (SMS) or the WhatsApp application.

Fever information triggered a home medical evaluation (Figure 2). 
Figure 2: Medical evaluation flowchart of febrile cases in dengue cohort at Goiania-GO, Brazil, 2015-2019.

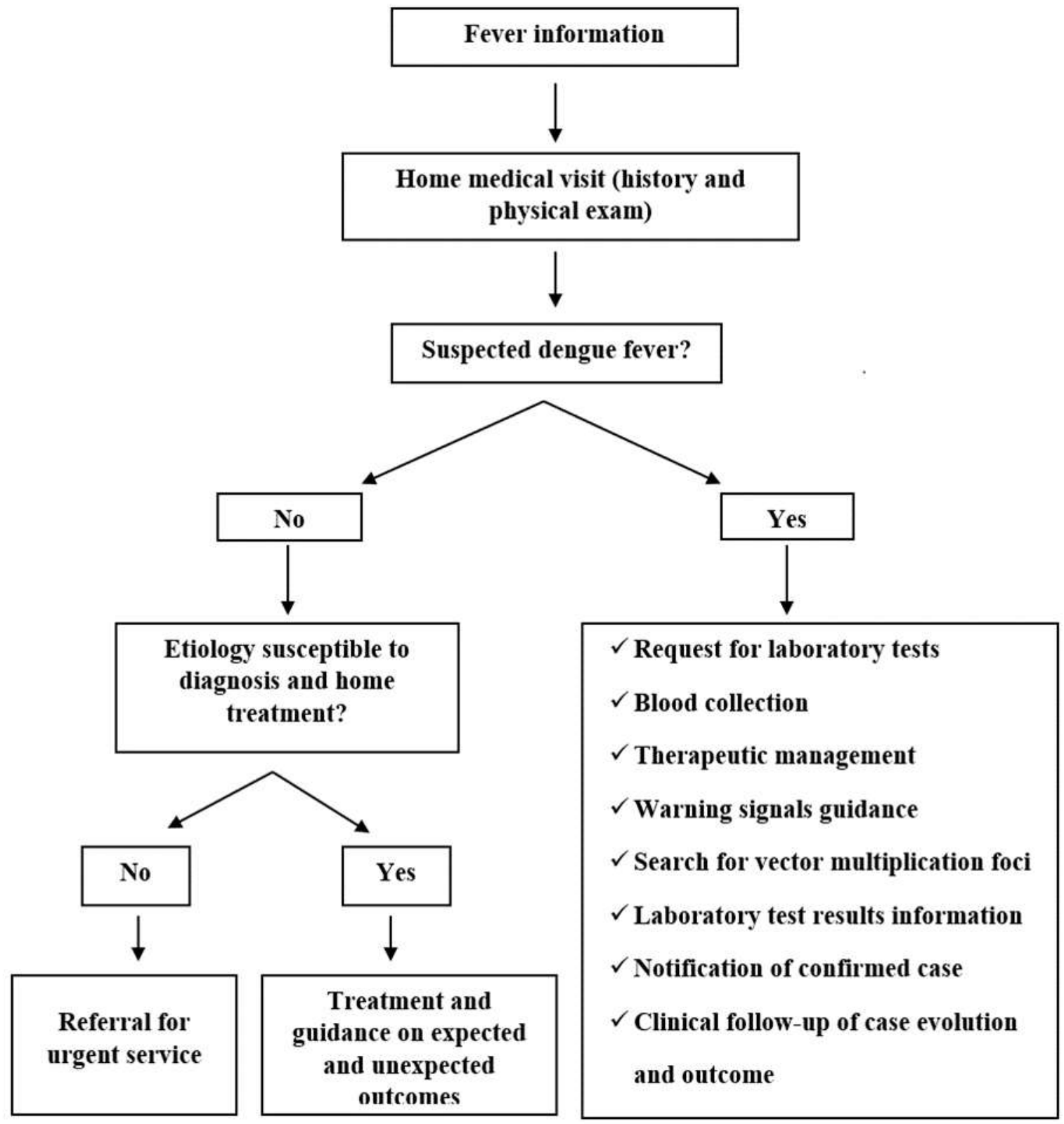

Source: Authors.

Through clinical history and physical examination, the physician checked for suspected dengue. Two conclusions were possible:

1. Without suspected dengue: when it was possible to treat the cause of the fever at home, the physician instituted the treatment and monitored the evolution of the case and provided guidance on possible unexpected outcomes. Otherwise, he referred to the emergency department for fever assessment and management.

2. With suspected dengue: the health team performed the following procedures:

- The physician requested additional tests to confirm the diagnosis of the disease: nonspecific (blood count) and diagnostic tests (NS1 antigen, anti-dengue IgM antibodies and viral genome detection by RT-PCR).

- The nurses collected the exams.

- The physician indicated the treatment and provided guidance on the warning signs of disease severity. 
- The physician searched for vector multiplication foci

- The physician explained the test results.

- The physician notified the confirmed case.

- The physician, nurses and CHA monitored the clinical evolution.

- The physician made the classification of the final clinical outcome of the case.

\section{Discussion}

Longitudinal studies pose a number of challenges for researchers in their conduct. In this article, we present the strategies used to implant and conduct a cohort of children and adolescents to monitor the occurrence of potential dengue cases. Alternatives to the difficulties and limitations observed in this process were also described.

The meetings for the qualification of the project team members were essential for the individual understanding and implementation of a systematic routine of conduct related to the initial serological survey and evaluation of febrile conditions. The pilot evaluation was important to improve the flow of activities and action fronts, eliminating doubts and reducing the errors identified in the evaluation.

Partnering with day care centers, schools and churches was important for spreading and understanding the project's goals in the community. Although no critical points were identified for the study in this initial contact with these institutions, they provided security for families when visited by field teams. This strategy was also adopted in a Phase III preparation study for a clinical trial of a dengue vaccine in Brazil, where meetings were held with key informants, including health professionals, teachers, and community members to facilitate dissemination of the project and participation of the guests (Dayan, 2015).

The conduct of clinical and epidemiological field research supported by public health services has been described, presenting the advantages and challenges of this collaboration (Jaenisch et al., 2016; Kuan et al., 2009, Martínez-Veja et al., 2016). In this context, conducting this study in partnership with public health services showed benefits for the project and for the health service. From the project's perspective, the managers indicated a territory where the FHST could assist in the dissemination of the project and suggest families with children and adolescents in the study age group. Knowledge of the characteristics of the population attended by FHST allowed the indication of locations with lower histories of migratory processes to avoid participants' loss of follow-up, a limitation of cohort studies (Eldredge, 2002). This strategy was also adopted previously in other cohorts of children with dengue carried out in Thailand, in which the choice of region for the research was also based on the stability of the local population (Sirivichayakul et al., 2012; Tissera et al., 2014). In contrast, the provision of home care for febrile children benefited the municipal health system from two perspectives: 1) reduction in the number of medical appointments at USF and Emergency Care Units and 2) notification of confirmed cases of dengue to the surveillance service, since laboratory confirmation occurred within a maximum of three days. Although reporting only confirmed cases is not the routine adopted by the dengue surveillance system, the short time to perform confirmatory tests offered this service the possibility of more timely and accurate action. In general, vector control activities are initiated without laboratory confirmation of the cases, as the traditional surveillance system routine usually has an interval of more than seven days to receive specific test results (Mandacarú, 2012).

Another important point to be emphasized was the impact of the presence of an SMS manager in meetings with the FHST. In the presence of this manager, a greater presence and involvement of the teams was observed.

In this study, initial blood collection was a cause of refusal to participate, especially for children under four years of age. Jaenish et al. (2016), in a multicenter cohort conducted between 2011 and 2016, chose to exclude children under five years of age to avoid the inconvenience of blood collection in this age group. In a cohort of suspected dengue fever cases in Nicaragua (2004-2008), at the time of receiving the annual survey result, participants were given a participation stimulus for a 
school kit (Kuan et al., 2009). In Thailand, each family of participants in a dengue cohort (2008-2010) received, at the time of registration, a thermometer to measure body temperature (Tissera et al., 2014). In our context, no type of adhesion stimulus was used, in accordance with Brazilian legislation (National Health Council Resolution $n^{\circ}$ 466/2012) (Brasil, 2012). However, home visiting and the existence of a pediatrician dedicated to the project were strategies adopted for the permanence of the study participants. Still in this perspective, the option of direct contact of the physician with the participants' guardians to inform the results of the exams, from the serology performed during the recruitment to the results of the exams of the feverish conditions, was made with the purpose of narrowing the relationship with the participants, favor communication between families in the project neighborhoods and consequently the reduction of participation refusals and future follow-up losses.

Regarding the monitoring of fevers, it was initially thought that the most appropriate communication strategy would be the weekly telephone call, as reported in another cohort aimed at monitoring acute infectious diseases (Yoon et al., 2015). However, many families only attended at night, outside business hours, leading to the need to set up this work period. Over time, those responsible began to use phone calls and especially messages through the WhatsApp application directly to the doctor as the main means of reporting the occurrence of fever. This application was indeed very useful for communicating with families, establishing the exchange of information quickly and synchronously. The use of short messages to report the onset of fever has also been used in a cohort to assess dengue incidence in Brazil (Pedro et al., 2019) and in the Philippines (Alera et al., 2016).

Generally, the follow-up of febrile conditions in cohorts are performed in health units that were part of the research or by nurses in home evaluation (Kuan et al., 2009; Yoon et al., 2015). In our study, home pediatric consultations allowed us to establish a close bond with many registered families. However, this bond favored the physician's call for clinical evaluations different from the project proposal. This has become a challenge, which was partially addressed by the team's constant explanation of the research objectives, which did not foresee the replacement of the health system, as well as evaluations of other non-dengue-related complaints.

\section{Final Considerations}

Field research in Brazil has been challenging, as the scientific mindset is not yet fully incorporated into society. The partnership between academia and health services may be an appropriate strategy in this perspective. The contribution of the MHS and FHS management team was essential for the proper implementation and conduct of this study. In return, the researchers' performance favored the Health Service through surveillance and health care activities of the population. This interinstitutional experience was successful, with benefits for both institutions.

The experience of this project and similar reports can contribute to future research in our country and other settings, specially under the perspective of field work.

\section{References}

Alera, M. T., Srikiatkhachorn, A., Velasco, J. M., Tac-Na, I. A., Lago, C. B., Clapham, H. E., \& et al (2016). Incidence of dengue virus infection in adults and children in a prospective longitudinal cohort in the Philippines. PLoS Negl Trop Dis, 10(2), 1-14. 10.1371/journal.pntd.0004337

Araújo, H., Carvalho, D., Ioshino, R., Costa-da-Silva, A., \& Capurro, M. (2015). Aedes aegypti control strategies in Brazil: incorporation of new technologies to overcome the persistence of dengue epidemics. Insects, 6(2), 576-594. 10.3390/insects6020576

Baldacchino, F., Caputo, B., Chandre, F., Drago, A., della Torre, A., Montarsi, F., \& et al (2015). Control methods against invasive Aedes mosquitoes in Europe: a review. Pest Manag Sci, 71(11), 1471-1485. 10.1002/ps.4044

Brasil. Ministério da Saúde (2012). https://bvsms.saude.gov.br/bvs/saudelegis/cns/2013/res0466_12_12_2012.html

Brasil. Ministério da Saúde (2015). https://portalarquivos.saude.gov.br/images/PDF/2015/julho/29/Dengue-at---2014.pdf.

Brasil. Ministério da Saúde (2017). https://bvsms.saude.gov.br/bvs/saudelegis/gm/2017/prt2436_22_09_2017.html 
Dayan, G., Arredondo, J. L., Carrasquilla, G., Deseda, C. C., Dietze, R., Luz, K., \& et al (2015). Prospective cohort study with active surveillance for fever in four dengue endemic countries in Latin America. Am J Trop Med Hyg, 93(1), 18-23.

Eldredge, J. (2002). Cohort studies in health sciences librarianship. J Med Libr Assoc, 90(4), 380-392.

Goiânia (2019). https://saude.goiania.go.gov.br/wp-uploads/sites/3/2020/05/Informe_Semanal_Den_Chik_Zika_16_07_19_SE_28.pdf

Grollmus, N. S., \& Tarrès, J. P. (2015). Relatos metodológicos: difractando experiências narrativas de investigación. Fórum Qualitative Social Research, $16(2), 1-24$

Guzman, M. G., \& Harris E. (2015). Dengue. Lancet, 385(9966). 453-465. 10.1016/S0140-6736(14)60572-9

IBGE (2015). https://cidades.ibge.gov.br/brasil/go/goiania/panorama.

Jaenisch, T., Tam, D. T. H., Kieu, N. T. T., Van-Ngoc, T., Nam, N. T., Van-Kinh, N., et al (2016). Clinical evaluation of dengue and identification of risk factors for severe disease: protocol for a multicentre study in 8 countries. BMC Infect Dis, 16(1), 120. 10.1186/s12879-016-1440-3

Kuan, G., Gordon, A., Aviles, W., Ortega, O., Hammond, S. N., Elizondo, D., et al (2009). The Nicaraguan pediatric dengue cohort study: study design, methods, use of information technology, and extension to other infectious diseases. Am J Epidemiol, 170(1), 120-129. 10.1093/aje/kwp092

Luz, P. M., Codeço, C. T., Massad, E., \& Struchiner, C. J. (2003). Uncertainties regarding dengue modeling in Rio de Janeiro, Brazil. Mem Inst Oswaldo Cruz, 98(7), 871-878. https://doi.org/10.1590/S0074-02762003000700002

Mandacarú, P. M. P. (2012). Timeliness of the dengue, exanthematic diseases, meningitis and tuberculosis surveillance systems in Brazil. Dissertação (Mestrado). 106 f. Instituto de Patologia Tropical e Saúde Pública. Universidade Federal de Goias.

Martina, B. E. E., Koraka, P., \& Osterhaus A. D. M. E. (2009). Dengue virus pathogenesis: an integrated view. Clin Microbiol Ver, 22(4), 564-581. 10.1128/CMR.00035-09

Martínez-Vega, R. A., Rodriguez-Morales, A. J., Bracho-Churio, Y. T., Castro-Salas, M. E., Galvis-Ovallos, F., Díaz-Quijano, R. G., \& et al (2016). A prospective cohort study to assess seroprevalence, incidence, knowledge, attitudes and practices, willingness to pay for vaccine and related risk factors in dengue in a high incidence setting. BMC Infect Dis, 16(1), 705. 10.1186/s12879-016-2055-4

Medronho, R. A., Macrini, L., Novellino, D. M., Lagrotta, M. T. F., Câmara, V. M., \& Pedreira, C. E. (2009). Aedes aegypti immature forms distribution according to type of breeding site. Am J Trop Med Hyg, 80(3), 401-404. https://doi.org/10.4269/ajtmh.2009.80.401

Pedro, R. S., Carvalho, M. S., Girianelli, V. R., Damasceno, L. S., Leal, I., Cunha, D. C., \& et al (2019). A populational-based birth cohort study in a lowincome urban area in Rio de Janeiro, Brazil: implementation and description of the characteristics of the study. Cad. Saúde Pública, 35(5), 1-14. e00023918. https://doi.org/10.1590/0102-311X00023918

Simmons, C. P., Farrar, J. J., Nguyen-van, V. C., \& Wills, B. Dengue (2012). N Engl J Med, 366(15), 1423-1432. 10.1056/NEJMra1110265

Siqueira, J. B., Martelli, C. M. T., Maciel, I. J., Oliveira, R. M., Ribeiro, M. G., Amorim, F. P., \& et al (2004). Household survey of dengue infection in central Brazil: spatial point pattern analysis and risk factors assessment. Am J Trop Med Hyg, 71(5), 646-651.

Sirivichayakul, C., Limkittikul, K.., Chanthavanich, P., Jiwariyavej, V., Chokejindachai, W., Pengsaa, K., \& et al (2012). Dengue infection in children in Ratchaburi, Thailand: a cohort study. ii. clinical manifestations. PLoS Negl Trop Dis, 6(2), 1-10. e1520. 10.1371/journal.pntd.0001520

Tissera, H., Amarasinghe, A., Silva, A. D., Kariyawasam, P., Corbett, K. S., Katzelnick, L., \& et al (2014). Burden of dengue infection and disease in a pediatric cohort in urban Sri Lanka. Am J Trop Med Hyg, 91(1), 132-137. 10.4269/ajtmh.13-0540

WHO (2009). https://www.who.int/tdr/publications/documents/dengue-diagnosis.pdf

WHO (2012). https://apps.who.int/iris/bitstream/handle/10665/75303/9789241504034_eng.pdf?sequence=1\&isAllowed=y

Yoksan, S., Tubthong, K., Kanitwithayanun, W., \& Jirakanjanakit, N. (2009). Laboratory assays and field dengue vaccine evaluation at Ratchaburi Province, Thailand: a preliminary result. J Clin Virol, 46 (Supl.2), S13-15. 10.1016/S1386-6532(09)70289-6

Yoon, I. K., Alera, M. T., Lago, C. B., Tac-An, I. A., Villa, D., Fernandez, S., \& et al (2015). High rate of subclinical chikungunya virus infection and association of neutralizing antibody with protection in a prospective cohort in the Philippines. PLoS Negl Trop Dis, 9(5), 1-14. 10.1371/journal.pntd.0003764 